\title{
RELATIONS BETWEEN THE LIVING AND THE DEAD IN ESTONIAN FOLK RELIGION
}

\section{Eha Viluoja}

The relations between the living and the dead could be divided into the normal (i.e. accepted by the tradition) and the abnormal ones (i.e. condemned by the tradition).

The first group of them included the customs associated with the ancestral cult expressed in the observance of the so-called souls' time. Estonians kept the time of visiting soul's in autumn, depending on the region during the period from Michaelmas to Christmas. To be more exact: either round Michaelmas (September 29), before Martinmas (November 10), between Martinmas and St. Catherine's Day (November 25) or before Christmas (Loorits 1957: 184-204; Hiiemäe 1995: 124129). The dead ancestors were anticipated to visit their former farmstead during souls' time. Thus, in the threshing-room there was laid the table for the souls or they were taken some food in a bowl to the loft or some farmstead building. It was done on one or several evenings. The proper treatment of the ancestors was believed to have a good influence on the destiny of the living. There is even a proverb, "Whose souls are hungry, theirs fields are poorly" (Tarvastu parish) (EV 1980: no. 1282). This does not indicate, however, to an application for the active support from the part of the deseased but rather it tries to avoid any possible damage.

The people of the South-East Estonia, the Setus, who unlike the Estonian Lutheran majority, are Orthodox, thought the dead soul to wander about its homestead during the six weeks after the person's death. They also were and are still practicing the commemoration feasts on the graves of the dead on certain fixed dates (six weeks, half a year, a year, three years) after the death of the person as well as on some calendar holidays.

According to the beliefs the dead could come home also outside the traditionally prescribed period. It was considered to be a token of a violation of a norm either by the dead during his/her lifetime or by the living. Such a dead was called kodukäija (=home-wanderer, revenant).

At the latest, the souls' time was ceased to be celebrated at the beginning of the present century, the legends and especially the memorates about the revenant, however, are retold also at present. The situation is reflected in the file of the Estonian Folklore Archives, the centre containing the majority of the Estonian folklore collections, in the following way: there are over seven times more material concerning the revenant than that concerning the souls' time. Hereby mention should be made that extensive collecting of the Estonian folklore was initiated in the last quarter of the previous century.

L. Simonsuuri divides in his type and motif list of Finnish belief legends the revenants into the groups of the guilty, the innocent and the others (Simonsuuri 1961). J. Pentikäinen in his turn distinguishes among the innocent revenants the solicitous, the avengers and the dissatisfied (Pentikäinen 1968: 64). Thus, in order to understand why a revenant was assumed to behave in a particular way as well as what the living are supposed to do in order to avoid or stop homewandering, one has to consider the causes of home-wandering. The present paper will try to present the 


\section{possible causes in a schematic way. The scheme is based on three groups of attributes.}

(The arrows symbolize the direction of impact or action; the opposite arrows $(><)$ denote reciprocal relations between the living and the dead.)

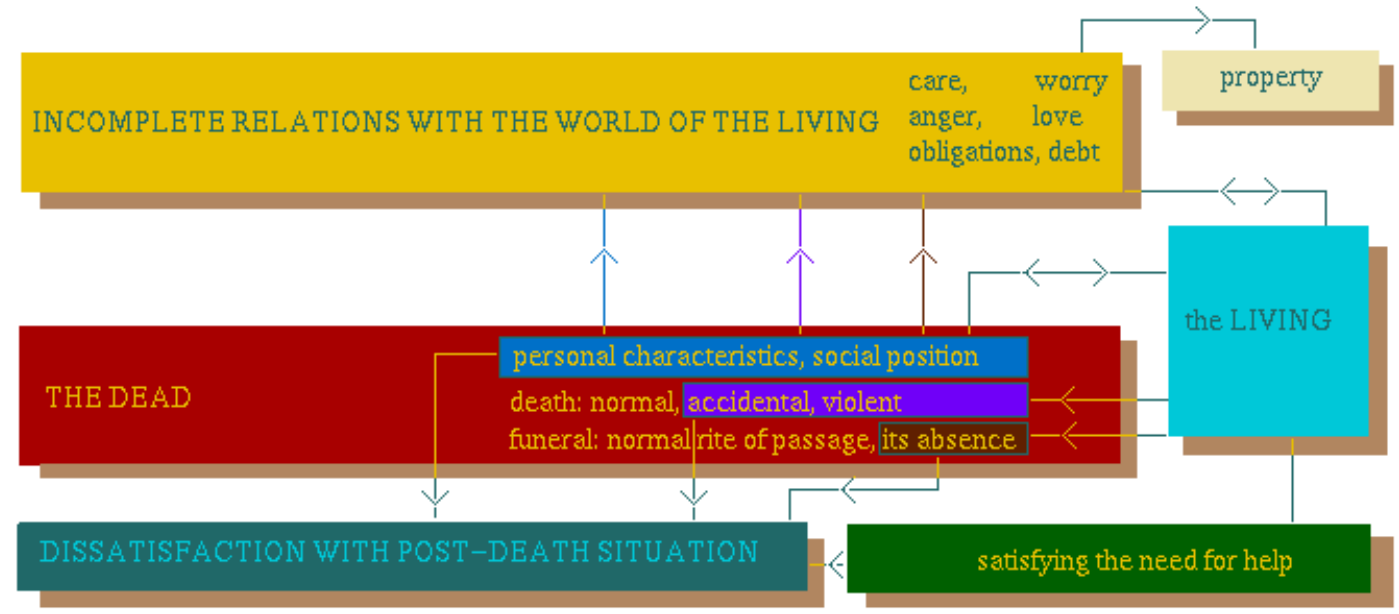

1. Personal attributes of the dead, its social position and relations with the other people at one's life time.

The persons of spiteful on envious character and those who were thought to be witches were feared because of their possible homewandering. As the majority of the material represents village society, the tendency towards home-wandering was ascribed to the persons differing from average peasant: old bachelors and spinsters, the poor of the community but also the especially rich, the landlords and the members of their families. It was also believed that home-wandering may be caused by unfulfilled duties, care, worry, hatered and love while they could be felt by the dead towards the living but also by the living towards the dead. Familiar are the warning legends which admonish to keep from the excessive weeping for the dead.

2. Sudden, accidental or violent death.

Actually the causes mentioned here can be reduced to the third reason:

3. The lack or deficiency of the rite of passage.

The final rite of passage of human life which was to take a person from the status of the living into the status of the dead took its course already while preparing the dying for death by keeping guard at the person - dying alone was thought to be a very bad in its essence -, by the appropriate behaviour at the moment of death and it was later continued with the traditional treatment of the corpse (washing, clothing, keeping guard again, etc.). In case with sudden, accidental or violent death a part of the components of the rite of passage (or in case the corpse was not found - all of them) remained unfulfilled. With a violent death there could be an additional motif of revenge or the necessity to find the criminal.

An important part of the rite of passage was the funeral and the funeral feast. It was necessary to conduct them as the custom prescribed but the wishes of the deseased were to be considered as well. Mistakes made hereby could cause home-wandering. 
Not every revenant narrative reveals the cause of home-wandering. It may be that the informant wonders why the person, so nice while living, took after his/her death to home-wandering.

All the three groups of causes lead to two results (although by different ways) and namely: (1) incomplete relationship with the word of the living and (2) dissatisfaction with the situation after death.

Revenant's attitude towards the living can be either benevolent, neutral or hostile.

Caring revenant is met only in the narrow circle of legends and memorates. Actually here belong only the narratives about the parents who worry about their children or the family left behind. There are also a few memorates about the worried father ("I came to have a look how our mother with her numerous children can manage!" (ERA II 169, 66/7 (149) <Vändra, 1937)) or about the father giving advice to his son and being, to tell the truth, annoyed by the fact that his son wastes money on lawyer although the justice is on his side anyhow (ERA II 166, 55/6 (37) < Jõhvi < Lüganuse, 1937). The best-known legend type is that about the dead mother who still comes to take care of her baby (met also at the Finns (Simonsuuri C 411)). The contacts with the deceased, however, are not always harmless. For example, in one legend the dead mother promises to take her sick child with her because the father does not take good care of the child. The child dies. (ERA II 138, 576/7 (67) $<$ Tartu 1. < Hargla, 1937.)

Familiar are also the legends and memorates where the dead husband visits his wife. While in the internationally spread legend types ( $\mathrm{J} \mathrm{C} \mathrm{418,} \mathrm{J} \mathrm{C} \mathrm{479)} \mathrm{the} \mathrm{husband} \mathrm{turns} \mathrm{out} \mathrm{to} \mathrm{be} \mathrm{the} \mathrm{devil,} \mathrm{in} \mathrm{the}$ local legends and memorates this cannot be avered.

Neutral revenant appears most frequently either at home or its surroundings as a visual, auditory or tactile being or phenomenon. Sometimes the homewandering of the dead is deduced from the indirect signs (traces or lost things) or from the behaviour of the animals.

The appearance of the dead at home is caused by dissatisfaction with the post-death situation. This may be due to the unpleasant neighbour at the graveyard, bad place of burial, etc. The dead may appear also in dreams and tell the seer the reasons for his dissatisfaction. Another cause for dissatisfaction may be the bad character of the dead itself. In the legend (S C 376) the dead mistress comes home to eat the pigs' fodder because while living she had been stingy and given nothing for the beggars and now she herself has got nothing to eat.

Attachment to one's property or the life-long activity, the dead has not got rid of after the death, may force it to return home to look for or to move one's things (J C 434), to clatter with tools, to call the animals. The living become aware of the dead person's presence in those cases mostly by auditory, seldom by visual perceptions.

Even if the dead's activities are not wilfully directed against the living, it usually disturbs the latter (noise, moving of things, etc.). But the homewandering may result also in economic damage. Especially if the dead is resentful towards the living. In the legend the dead mistress calls her cow at night and the milking of the cows is being heard. At the result of this the cows fall ill one after another and die. It is all because the children did not have the heart to slaughter for their mother's funeral the best milk cow as she had wished (H I 10, $245(5)<$ Vastseliina ). Therefore the belief accounts and the legends warn us that the wish of the dying has to be fulfilled: if he/she is not given what he/she has asked for and what belongs to him/her, he/she will come and take it himself. The mistakes made by the living at the funeral, the debt owed to the dead or bad relations with the relatives or the neighbours may cause the revenant to accuse the living, to demand the debt back, to attack people, to strangle them. There are memorates and local legends as well as legends of fixed type spread widely about the aggressive dead. The latter include the legends about the dead who 
becomes active before the funerals already: attacs the vigil-keeper (S C 101, J C 112), or the undertaker on the way to graveyard (Aa S 3, S C 231) but also after the funerals: the dead girl rises from the grave to look for the hidden farm-hand (Aa S 8), the dead landlord comes home to torture the animals and his wife (Aa S 6), the dead leaves the grave to put the bridal couple in their wedding to death (Aa S 7), the dead or the devil fights with a wayfarer in the moonlight - wins the one who manages to turn to the moon so that his shadow falls on his adversary (Aa S 35). One has to admit that those established legends do not reflect usually contemporary beliefs.

Known are also local legends where the dead is met as a nightmare, it tortures, pesters or threatens somebody, attacks some person.

Agressive behaviour of the dead may cause a person's illness or death.

However, the dead of the blood-thirsty vampire type are not met in Estonia.

Alongside with the so-called constant revenants there are accounts about a single appearance of a person after his death.

Depending on the behaviour of the home-wanderer the family may accept the revenant quite favourably. It has been said that people got used to the revenant and finally the home-wandering came to an end.

Still, the numerous descriptions of the preventive measures taken to avoid home-wandering show that there were sought possibilities to do away with the practice. When there were some reasons to suspect later home-wandering, there were taken steps against it already during the funeral.

If possible, the cause for homewandering was tried to remove. For the dead to find peace prayers were read at church, the pastor was asked to bless the grave once more or the burial words read once again at the grave. When the cause was considered to lie in the poor funeral feast, an animal was slaughtered (it can be considered also an offering for the dead to reconcile him) and a new commemoration feast was held. Donations for the beggars served the same end. But the donations for the beggars could also compensate for the life-long stinginess of the dead (S C 376).

The methods of revenant prevention as well as the means for getting rid of the revenant can be divided into six functional groups (Viluoja 1992).

1. Ending the contact between the deceased and his former environment.

It was aimed already at the rite of separation. If the dead still happened to come home, the clothes or some other things belonging to him were taken at some place of the way to graveyard or to the grave, hoping that the dead would not pass the thing.

2. The deprivation of the deseased of his alleged ability to move (special way of clothing, binding of his limbs or crippling of the corpse).

3. Misleading of the dead: the footprints of the mourners were swept, way to the graveyard or back was made very complicated, the coffin was turned about or taken round some object (stone, juniper, grave).

4. Creating barriers between the living and the dead as the threshold, gate, cross-road being magically secured with the sign of the cross, knife, metal, salt or linen seeds or in some other way. After the dead were thrown some things or substances hoping that they would hinder the returning dead; the dead was taken over a river or fence because according to the belief the revenant cannot pass these barriers. 
5. The shutting of the dead into the coffin or grave (the grave was signified by preventive signs, or magically preventive substances or things were thrown into the grave; with the left foot there was knocked at the coffin or the grave; the dead was buried with its face downwards).

6. The destroying of the revenant which was performed at the supposed encounter with him.

The revenant was advised to be beaten with a stick of rowan or juniper or with a whip with 9 knots in it and with sharp instruments. The revenant was shot at with silver bullet or some other small silver item as well as with quicksilver. To destroy a revenant it was advised to shoot a silver bullet into the north wind or quicksilver into the east wind (ERA II 21, 336 (31) < Häädemeeste). For self-defence one could check the revenant by a sign of the cross or by spitting (E, StK 36, 7/8 $(9)<$ Võnnu, 1926). (Spit as the place where the vital energy is stored has been treated, for instance, by Oskar Loorits in 1932.) One could also recite the Lord's Prayer which was done 3 times or backwards, call the Lord's name or curse the revenant to the wolves (mentioned in the belief accounts, memorates as well as legends). Wolves or the dogs of St. George were considered fatal to the revenant like the lightning. Certain protection from the revenant was also expected of a dog, especially of the so-called four-eyed (brown sports above the eyes) dog. The activity of the revenant was cut off for the time by a cock's crow.

In revenant prevention the arts are often complemented with word magic (Viluoja 1978).

The current article is based on a paper presented at IAHR 1990 Regional Conference on Circumpolar and Northern Religion, held in Helsinki, Finland, May 13 - 19, 1990.

\section{References}

\section{Manuscripts}

ERA $=$ Folklore collection of the Estonian Folklore Archives (1927 - 1944).

$\mathrm{E}, \mathrm{StK}=$ Folklore collection of the Estonian Students' Society (1921-1927)

$\mathrm{H}=$ Folklore collection of J. Hurt (1860 - 1906).

\section{Publications}

Aa S = Aarne, Antti 1918. Estnische Märchen- und Sagenvarianten. FF Communications No. 25. Hamina.

EV 1980 = Eesti vanasõnad. I. Edited by Arvo Krikmann and Ingrid Sarv. Monumenta Estoniae Antiquae III. Tallinn.

Hiiemäe, Mall 1995. Souls' Visiting Time in the Estonian Folk Calendar. Folk Belief Today. Edited by Mare Kõiva and Kai Vassiljeva, pp. 124 - 129. Tartu.

$\mathrm{J}=$ Jauhiainen, Marjatta 1972. Täydennyksiä uskomustarinoiden tyyppiluetteloon. Beiträge zur

Lauri Simonsuuri Typen- und Motivverzeichnis der finnischen mythischen Sagen. Helsinki.

Loorits, Oskar1932. Eesti rahvausundi maailmavaade. Tartu.

Loorits, Oskar 1957. Grundzüge des estnischen Volksglaubens. III. Skrifter utgivna av Kungl.

Gustav Adolfs Akademien för folklivsforskning 18: 3. Lund.

Pentikäinen, Juha 1968. The Nordic Dead-Child Tradition. Nordic Dead-Child Beings. A Study in

Comparative Religion. FF Communications No. 202. Helsinki.

$\mathrm{S}=$ Simonsuuri, Lauri 1961. Typen- und Motivverzeichnis der finnischen mythischen Sagen. FF

Communications No. 182. Helsinki. 
Viluoja, Eha 1978. Sõnamaagia kodukäija tõrjes. - Sõnast tekstini. Edited by Ü. Viks and V. Pall, pp. 117 - 135. Tallinn.

Viluoja, Eha 1992. Revenant Prevention in Estonian Folk Tradition. The Journal of Intercultural Studies. Extra Series No. 2. Edited by T. Koizumi \& T. Kikugawa. Uralic Studies Volume No. 2, pp. 105 - 109. Osaka. 